\title{
TOWARDS A NEW PROCEDURE TO SET UP GROUNDWATER THRESHOLD VALUES IN ACCORDANCE WITH THE PREVISIONS OF THE EC DIRECTIVE 2006/118: A CASE STUDY FROM ACHAIA AND CORINTHIA (GREECE)
}

\author{
Christoforidou P. ${ }^{1}$, Panagopoulos A. ${ }^{2}$, Voudouris K. ${ }^{3}$ \\ ${ }^{1}$ Chemical Engineering, MSc, Thessaloniki, Greece, parthena@bio.auth.gr \\ ${ }^{2}$ Land Reclamation Institute, National Agricultural Research Foundation, Sindos, \\ 574 00, Thessaloniki, Greece, panagopoulosa@gmail.com \\ ${ }^{3}$ Laboratory of Engineering Geology and Hydrogeology, Department of Geology, Aristotle University, \\ 54124 Thessaloniki,Greece,kvoudour@geo.auth.gr
}

\begin{abstract}
The EU Water Framework and Groundwater Directives stipulate that EU member states have to assess groundwater chemical status by the use of groundwater threshold values derived for the protection of dependent ecosystems and human health. In the EU's $6^{\text {th }}$ FP BRIDGE project "Background cRiteria for the IDentification of Groundwater thrEsholds", a methodology for the derivation of threshold values (TV) for groundwater bodies is proposed. Threshold values are quality standards for polluting substances in groundwater that need to be formulated by the Member States for the status assessment of groundwater bodies. These values represent the concentration of a pollutant that cannot be exceeded in order to protect both the environment and human health. The proposed method derives groundwater threshold values based on environmental objectives for groundwater "itself" as a receptor, using relevant reference criteria such as natural background levels, drinking and irrigation water standards. This methodology is tested on seven districts in Greece (two of them are analyzed in this paper). Concentrations of major ions, ammonium and data of electrical conductivity were examined. After a pre-selection on databases with groundwater samples the natural background level is determined as the 90- and 97.7 percentile.
\end{abstract}

Key words: Greece, groundwater, natural background level, threshold value, European groundwater directive, chemical status.

\section{Introduction}

Greece is a country which mainly depends on groundwater resources for its water supply. The types of aquifers that dominate are karst aquifers and coarse grained Neogene and Quaternary deposits (porous aquifers). The dominant hydrochemical type of groundwater in Greece is the one of $\mathrm{Ca}-\mathrm{Mg}-$ $\mathrm{HCO}_{3}$ representing freshwater of recent infiltration (Daskalaki and Voudouris, 2007).

The major water consumer is agriculture (86\%), with irrigated areas rapidly increasing in the last decades. Nitrate pollution due to agricultural activities (pesticides, fertilizers, etc), as well as due to existing cesspools used for untreated domestic effluent, has become a pressing and important problem nowadays. Sea intrusion is a second groundwater quality problem in Greece, mainly faced by 
overexploited coastal aquifers (Daskalaki and Voudouris, 2007).

According to the European groundwater directive, 'Member States should, where possible, use statistical procedures, provided they comply with international standards and contribute to the comparability of results of monitoring between Member States over long periods'. The main aim of BRIDGE project was to develop a methodology for setting up threshold values (TV) for groundwater, based on scientific principles.

Natural background levels and environmental quality standards or drinking water standards derived from (eco)toxicological tests etc., may be established by scientific methods (Edmunds et al., 2003; WHO, 2006). BRIDGE methodology uses for the derivation of threshold values (TV), natural background levels (NBL) and environmental quality standards (EQS) for 1) dependent aquatic ecosystems, and 2) groundwater "itself". In the latter case groundwater is protected as an ecosystem "itself" or as a source of water supply for human consumption for the protection of human health. Since little is known about water quality needs of groundwater ecosystems, surface water quality standards (EQS) or drinking water standards (DWS) may be chosen (Müller et al., 2006).

The derivation of groundwater threshold values based on environmental objectives for terrestrial ecosystems was not considered specifically, as also little is known about environmental quality standards for these. In general, drinking water standards as reference values for groundwater "itself" and irrigation standards were used.

The aim of the present work is to derive and evaluate the threshold values by means of the methodology described in WP3 of Bridge Project, enriched with some additional criteria. After a pre-selection on a database the natural background level is determined as the $90^{\text {th }}$ and $97.7^{\text {th }}$ percentile; both options are offered to decision makers, depending on the particularities of each study area. The threshold values are calculated by comparing the natural background level with a reference value, which is dependent on the receptor.

\section{Geological setting}

\section{NW Achaia}

The Glafkos basin aquifer system is located in the southwestern part of Greece (Peloponnese). Unconsolidated alluvial sediments with silty and clayey intercalations are dispersed throughout the Glafkos basin, especially in the coastal area (Fig. 1). The aquifers of the alternating coarse-grained alluvial beds may be regarded as one unified aquifer system (Lambrakis et al., 1997). The presence of silts and clays implies the occurrence of artesian conditions in the coastal part of the aquifer. Groundwater recharge takes place mainly by seepage through the riverbed and direct infiltration during rainfall. Based on borehole data analyses the depth of boreholes ranges between 40-140 m below mean sea level (Voudouris, 1995).

In the coastal part of this aquifer system seawater intrusion is evidenced due to overexploitation combined with prolonged dry periods. The waters are of various hydrochemical types: $\mathrm{Ca}-\mathrm{Mg}-\mathrm{HCO}$ (freshwater of recent infiltration), $\mathrm{Na}-\mathrm{HCO}_{3}$ (this type indicates ion-exchange phenomena and characterizes a transition zone) and $\mathrm{Na}-\mathrm{Cl}$ (typical brackish water in which the ions $\mathrm{Na}^{+}$and $\mathrm{Cl}^{-}$dominate).

\section{Coastal Corinthia}

The area, named Vocha plain, is located at the northeastern part of the Corinthia Prefecture and covers an area of $65 \mathrm{~km}^{2}$. It is characterized by ongoing urbanization, tourism development and inten- 


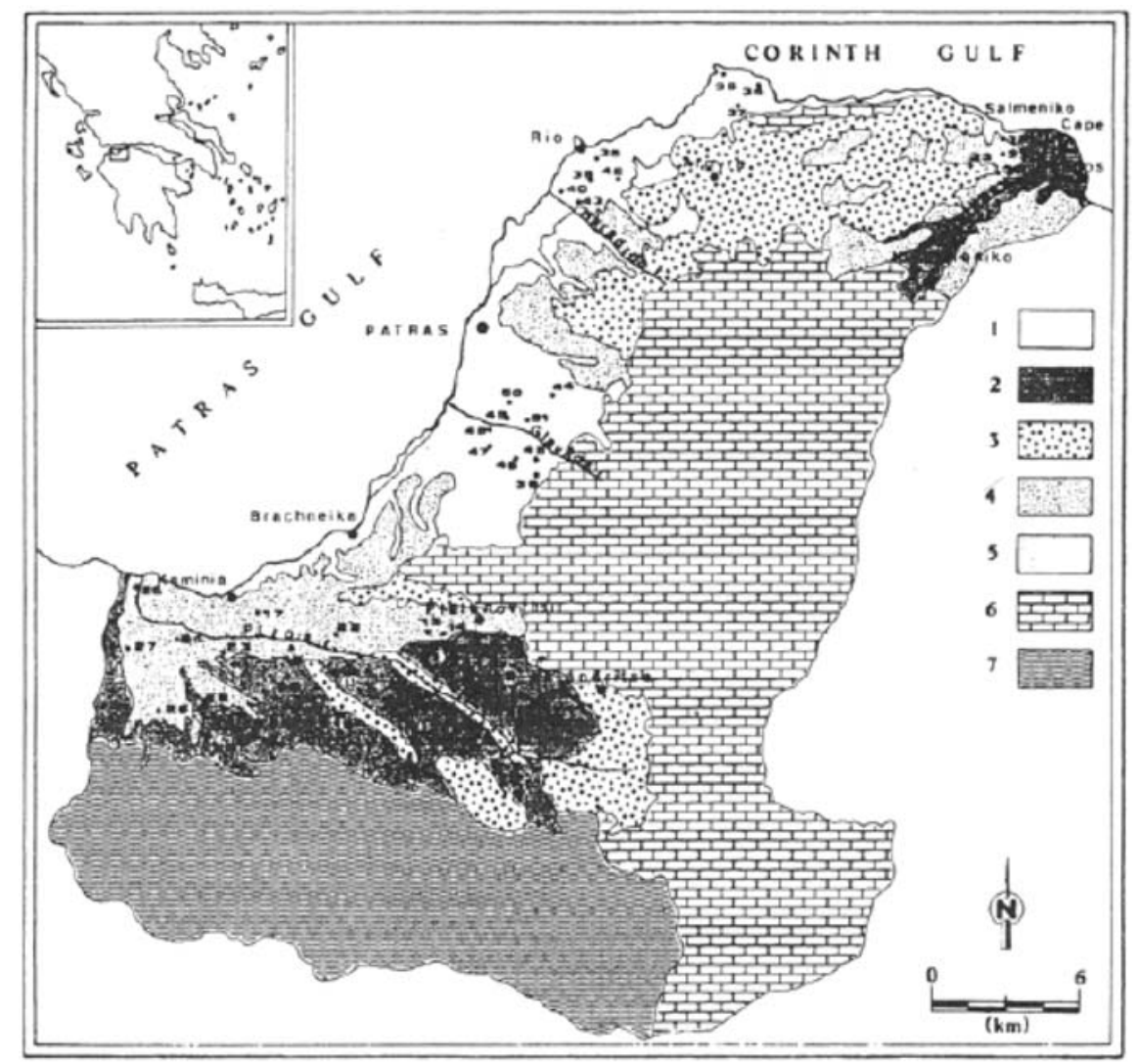

Fig. 1: Geological map of NW Achaia (Voudouris et al., 1997). 1. Recent alluvial deposits, 2. Terrestrial fluvial sediments, 3. Old alluvial deposits, 4. Clays, marls and sands, 5. Clays, siltstones, marls and silts with gravels, 6. Limestones, 7. Flysch.

sive agriculture that have considerable environmental impact, predominantly in the groundwater (Voudouris, 2006).

The area is formed of recent unconsolidated material consisting of sands, pebbles, breccias and fine clay to silty sand deposits (Fig. 2). The thickness of the plain's deposits varies from $30 \mathrm{~m}$ to $70 \mathrm{~m}$, whilst along the fluvio-torrential deposits of the river Asopos exceeds $100 \mathrm{~m}$. As a result of their origin the deposits are characterized by high degree of heterogeneity and anisotropy.

Within the alluvial deposits, successive confined or semi-confined aquifers and a superimposed phreatic aquifer exist. Their spatial extent is limited and on a regional scale they may be assumed to form a uniform aquifer system (Koumantakis et al., 1999). Mean groundwater level is 0.5-3 m below ground surface (b.g.s.) in the coastal area and 15-20 m b.g.s. inland, at the southern part of the study area. Highest levels are recorded in April or May and lowest in October.

Based on previous investigations (Voudouris et al., 2000; Panagopoulos et al., 2001), groundwater are of various hydrochemical types: $\mathrm{Ca}-\mathrm{HCO}_{3}$ is the dominant water type and is apparent adjacent to the main recharge zones of the aquifer system along the southern and especially the southwestern part of the studied area. $\mathrm{Na}-\mathrm{HCO}_{3}$ type, as well $\mathrm{Na}-\mathrm{SO}_{4}$ and $\mathrm{Na}-\mathrm{Cl}$ types, which are apparent far 


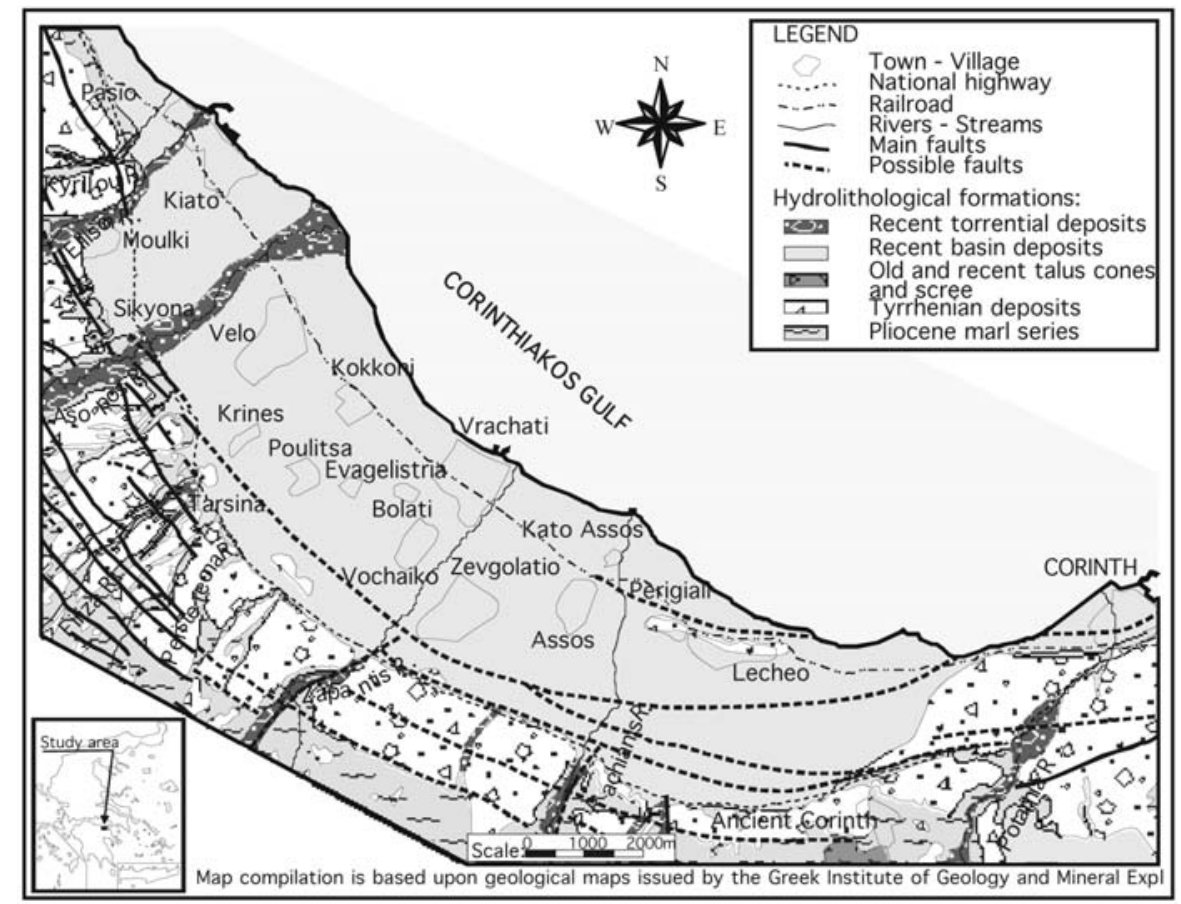

Fig. 2: Hydrolithological map of the northern coastal zone of Corinthia (Panagopoulos et al., 2002).

from the freshwater recharge zones, denote excessive mixing and ion exchange processes and saline water intrusion.

\section{Methods}

\subsection{General}

\section{Estimation of natural background levels (NBL)}

Natural background levels (NBL) play a key role as they are the starting point for the derivation of threshold values (TV). The methodology applied adopts a simplified pre-selection method, which uses the $90^{\text {th }}$ or $97.7^{\text {th }}$ percentile of a carefully selected dataset. The selection of the $90^{\text {th }}$ or $97.7^{\text {th }}$ percentile depends on the quantity and quality of the available data (Müller et al., 2006; Hinsby \& Condesso de Melo, 2006).

When a large dataset is available ( $>60$ points) the $97.7^{\text {th }}$ percentile is preferred. In cases of smaller datasets or when human impact cannot be excluded the $90^{\text {th }}$ percentile is recommended (Müller et al., 2006). The method may be applied if no national methodology exists or data do not allow for derivation of natural background levels by more advanced methods using environmental tracers, oxidation capacity or other pollution indicators etc.

Pre-selection criteria exclude (Müller et al., 2006).

- Samples with ionic balance error (IBE) $>10 \%$ (it is the minimum requirement for the quality of groundwater analyses): 
$\Sigma$ : sum of the concentrations of the ions in meq/l.

- Samples from unknown depth, samples that cannot be classified in any of the known aquifer types.

- Samples from hydrothermal aquifers.

- Data from salty aquifers ( $\mathrm{NaCl}$ content of more than 1,000 mg/l) (coastal or influenced by evaporites). These particular conditions are not identified in the typology and should be examined separately.

- Samples with nitrate concentration $>10 \mathrm{mg} / \mathrm{l}$ as they indicate human impact. The maximum admissible concentration (MAC) for the nitrates is $50 \mathrm{mg} / \mathrm{l}$, as set in the European Directive for water intended for human consumption (EU Directive 98/83).

- Samples with ion concentration $>$ Reference values (REF) as they indicate significant anthropogenic impact.

Data from anaerobic aquifers (DO $<1 \mathrm{mg} / \mathrm{l})$ should be studied separately, because in anaerobic conditions possible de-nitrification occurs in presence of carbon or pyrites (Griffionen et al., 2008). This may lead to inaccurate view about the actual concentration of nitrates, so additional pre-selection criteria should be used if possible. As in very few cases measurements of dissolved oxygen existed, an effort was made to implement a method proposed by Griffionen et al. (2008). This method is known as the oxidation capacity method (OXC). The use of OXC provides insight when nitrate reduction in association with pyrite oxidation is a relevant process. It is applied in fresh water samples $(\mathrm{Cl}<200 \mathrm{mg} / \mathrm{l})$, with $\mathrm{OXC}=7\left[\mathrm{SO}_{4}{ }^{2-}\right]+5\left[\mathrm{NO}_{3}{ }^{-}\right]$.

Where: OXC is the oxidation capacity in meq/l and the concentration of species is in $\mathrm{mmol} / \mathrm{l}$.

The values of 7 and 5 represent the amount of electrons transferred when $\mathrm{NO}_{3}{ }^{-}$reduces to $\mathrm{N}_{2}$ or $\mathrm{SO}_{4}{ }^{-}$reduces to $\mathrm{FeS}_{2}$, respectively. Samples having $[\mathrm{OXC}]>2$ meq/l are removed as they indicate anthropogenic influence.

\section{Threshold values (TV) derivation}

\section{Preliminary methodology}

The preliminary methodology suggests deriving threshold values based on the following three scenarios:

\footnotetext{
Case 1: NBL/REF $\geq 1 / 3 \rightarrow \mathrm{TV}=(\mathrm{NBL}+\mathrm{REF}) / 2$

Case 2: NBL/REF $<1 / 3 \rightarrow T V=2 x N B L$

Case 3: NBL/REF $\geq 1 \rightarrow \mathrm{TV}=\mathrm{NBL}$
}

Case 2 was removed from the final proposed method, as it led to small threshold values, difficult to be achieved and implemented in practice (Pauwels et al., 2007).

\section{Final methodology}

The methodology finally applied included only the following two scenarios:

Case 1: NBL/REF $<1 \rightarrow \mathrm{TV}=(\mathrm{NBL}+\mathrm{REF}) / 2$

Case $2: \mathrm{NBL} / \mathrm{REF} \geq 1 \rightarrow \mathrm{TV}=\mathrm{NBL}$

According to the European groundwater directive, any significant and sustained upward pollution 


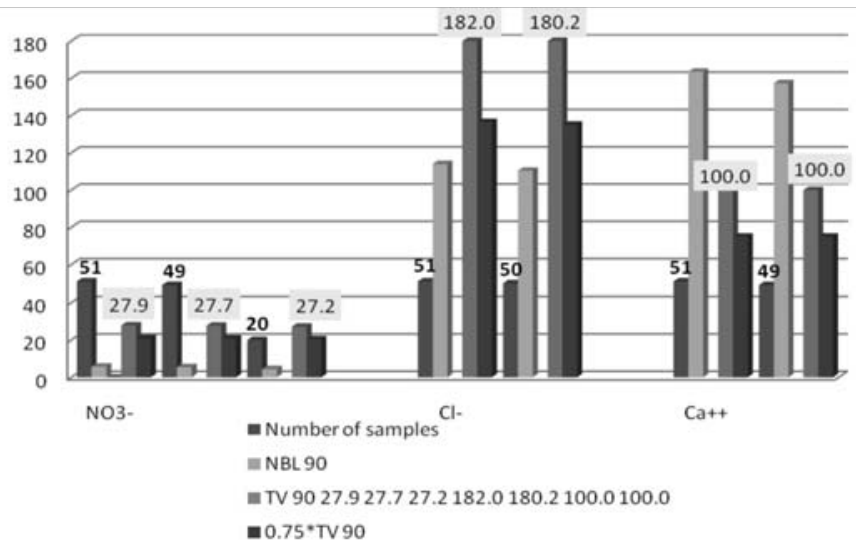

Fig. 3: Considered number of samples and corresponding values derived, NW Achaia basin. Varying number of considered samples relate to successive exclusion criteria applied on datasets as explained in the methodology section.

trend will have to be reversed when reaching $75 \%$ of the EU-wide groundwater quality standards and/or threshold values.

\section{Pollutants for TV derivation}

The pollutants considered for TV derivation were concentrations of major ions $\mathrm{Ca}^{2+,} \mathrm{Mg}^{2+}, \mathrm{Na}^{+}, \mathrm{K}^{+}$, $\mathrm{HCO}_{3}{ }^{-}, \mathrm{SO}_{4}{ }^{2-}, \mathrm{Cl}^{-}, \mathrm{NO}_{3}{ }^{-}, \mathrm{NH}_{4}{ }^{+}$and also electric conductivity (EC) values, that are often available in Greece. The reference values (REF) used were drinking water standards (DWS) (EU Directive 80/778 and EU Directive 98/83) and irrigation standards (Panoras \& Ilias, 1999). The standards considered relate to the most crucial for public health and the dominant water use in Greece, respectively.

\section{Selection of the reference quality standards}

The considered receptor should be defined (linked surface waters, dependent terrestrial ecosystems or groundwater 'itself'-groundwater protected against pollution on its own right) (EU Directive 2006/118). In the study areas considered in this paper, groundwater 'itself' is selected.

\subsection{Data analysis}

\section{NW Achaia}

The methodology was applied to 51 samples collected in May 1992 (Voudouris, 1995). As the number of samples is small $(\mathrm{N}<60)$, NBL 90 is selected and therefore TV 90 derived. There were no sample exclusions based on the ionic balance error $(\mathrm{IBE}>10 \%)$ and the salinity $\left(\left[\mathrm{Na}^{+}\right]+\left[\mathrm{Cl}^{-}\right]>1000 \mathrm{mg} / \mathrm{l}\right)$ criteria. TV's for nitrates were derived with the typical methodology (without taking into consideration possible anaerobic samples in datasets), as well as with the OXC method. 29 samples were additionally excluded when applying the OXC method.

Calculated TV's with both methods differ little with one another. TV 90 for nitrates was $\sim 27 \mathrm{mg} / 1$. High TV's of $\mathrm{Ca}^{2+}$ are attributed to the presence of $\mathrm{CaCO}_{3}$ in the basin's sediments, the extensive outcrop of limestones upstream and the influence imposed by the hydrochemical character of groundwater recharge water. Also saline intrusion in the coastal aquifers results in high TV's of $\mathrm{Na}^{+}$and $\mathrm{Cl}^{-}$ ions. In figure 3 concentrations of $\mathrm{NO}_{3}{ }^{-}, \mathrm{Cl}^{-}, \mathrm{Ca}^{2+}$ ions are presented in relation to the number of samples derived when applying the pre-selection criteria. 


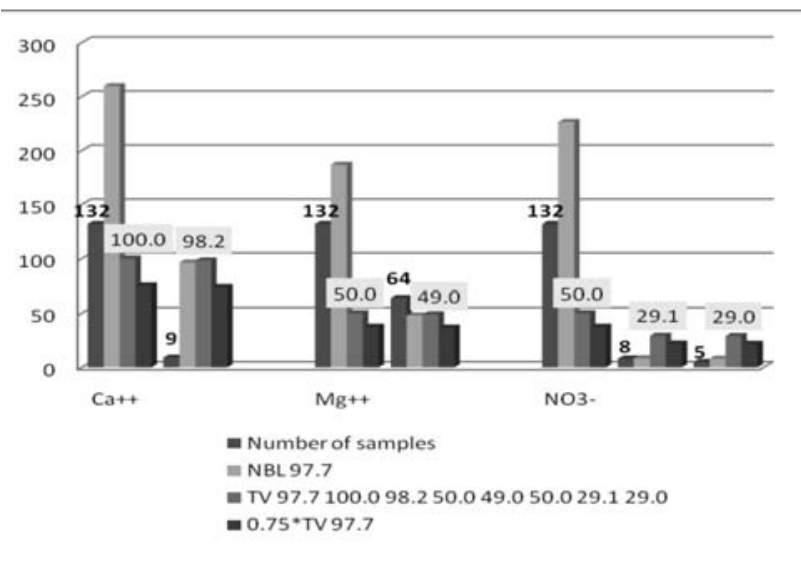

Fig. 4: Considered number of samples and corresponding values derived, coastal Corinthia basin-sampling period May 1997. Varying number of considered samples relate to successive exclusion criteria applied on datasets as explained in the methodology section.

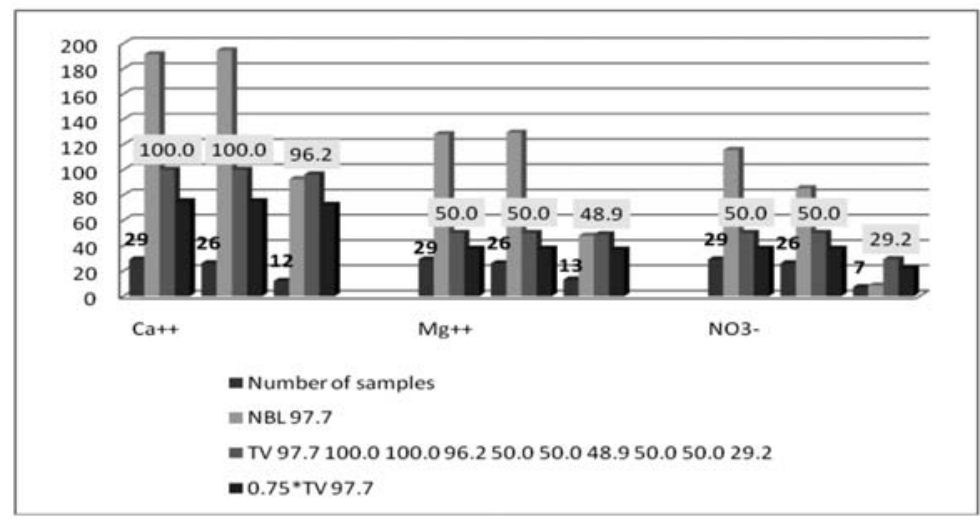

Fig. 5: Considered number of samples and corresponding values derived, coastal Corinthia basin-sampling period October 1997. Varying number of considered samples relate to successive exclusion criteria applied on datasets as explained in the methodology section.

\section{Coastal Corinthia}

A network of boreholes and wells distributed over the studied region was sampled in May 1997, October 1997 and May 1998, and 132, 29 and 69 samples were taken respectively. In all cases TV's for nitrates were derived with the OXC method as well. The values occurred differed a little from the conventional methodology. From the overview of the available data, it is expected that groundwater resources of coastal Corinthia are heavily polluted. This fact, along with the adequate number of samples available (>60), lead to the use of P97.7 for the estimations of NBL and TV's, as a less stringent approach. Average value of $7.0<\mathrm{pH}<8.0$ indicates slightly alkaline environment, while high conductivities are related to saline intrusion. Saline intrusion also results in increased values of $\mathrm{Na}^{+}$and $\mathrm{Cl}^{-}$concentrations. $\mathrm{Ca}^{2+}$ and $\mathrm{Mg}^{2+}$ ions also exhibit high concentrations along the main freshwater recharge zones (south and especially southwestern edge of the basin), and this is attributed to the origin of freshwater recharge and also to the high $\mathrm{CaCO}_{3}$ content of the aquifer matrix. This is illustrated in figures 4, 5 and 6 for the three sampling periods. Moderate to high $\mathrm{K}^{+}$ion concentrations are attributed to mixed-type fertilizers that contain nitrogen, potassium and phosphate (Voudouris et al, 2000). A great number of septic tanks which receive domestic wastewater, and in- 


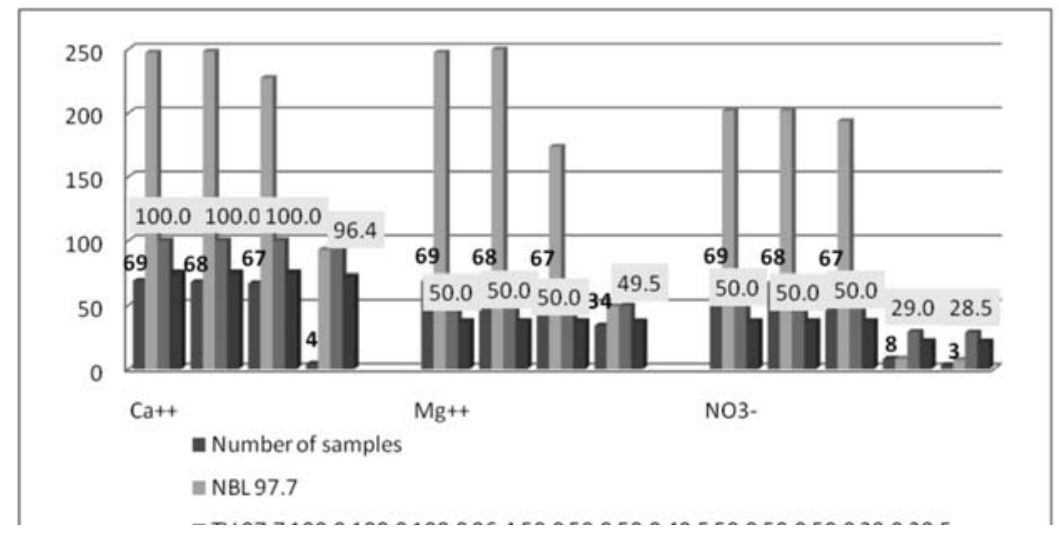

Fig. 6: Considered number of samples and corresponding values derived, coastal Corinthia basin-sampling period May 1998. Varying number of considered samples relate to successive exclusion criteria applied on datasets as explained in the methodology section.

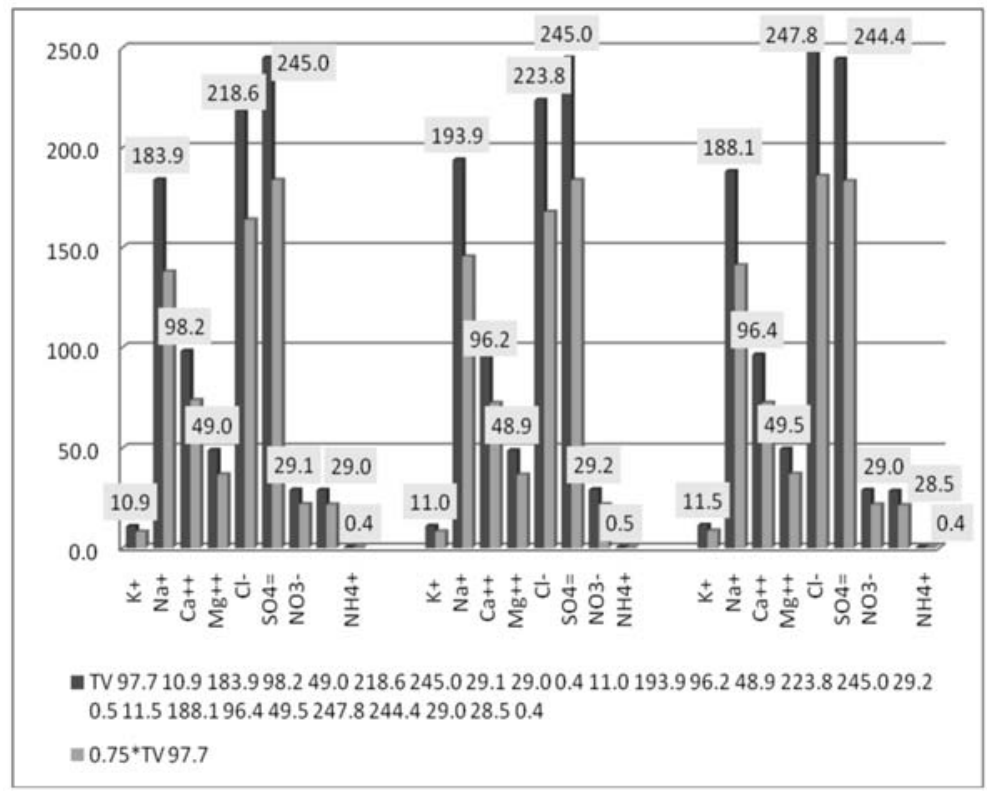

Fig. 7: Derived values for selected parameters over the 3 considered sampling periods, coastal Corinthia basin. Varying number of considered samples relate to successive exclusion criteria applied on datasets as explained in the methodology section.

tensified agricultural activities drive nitrates' concentrations to high levels. Occasional $\mathrm{NH}_{4}{ }^{+}$ion increased concentrations are recorded and attributed to organic matter fission.

As far as $\mathrm{Ca}^{2+}, \mathrm{Mg}^{2+}, \mathrm{SO}_{4}{ }^{2-}$ and $\mathrm{NH}_{4}{ }^{+}$ions are concerned, TV's are too close to the limit values of drinking water. For nitrates TV is close to $29 \mathrm{mg} / \mathrm{l}$. Figure 7 is representative of these facts and of course indicative of the significant degradation in groundwater's quality. 


\section{Conclusions-Results}

P.90.0 yields small values closer to the median approach, while P97.7 provides higher values that are easier to comply with. Alternatively, where possible threshold values for $\mathrm{NO}_{3}{ }^{-}$were derived using the OXC method. It was concluded that the calculated values differed a little from those derived employing the standard methodology.

P.90.0 proved to be a better approach towards establishing values that opt for environmental protection. On the other hand, P.97.7 would be an option for cases of heavily polluted groundwater bodies that is more realistic in terms of goals to be accomplished (reach values below the assigned TV). Overall, the proposed methodology provided reasonable results. It suggests a good measure of evolving pollution in a specific groundwater body, prior to reaching any used reference value that indicates in most cases an alarming and prohibitive for use condition, (e.g. the use of $50.0 \mathrm{mg} / \mathrm{l}$ for nitrates as set in the European Directive for water intended for human consumption).

Application of the presented methodology is a dynamic process combining scientific methods, monitoring data, practical experience and of course socio-economic impacts. Finally, given a groundwater body where a broad set of quality and quantity data is available, the option for NBL's estimation is to apply scientifically sound methods (e.g. hydrochemical simulations, component separation by concentration separation analysis). Clearly, the procedure described only accounts for substances which occur naturally, whereas for substances that are purely synthetic with no natural sources, the NBL should be set to zero (Pauwels et al., 2007).

In conclusion, the proposed methodology offers a great degree of freedom to member states to design and implement environmental protection policies that have a sound scientific basis and on the same time achieve a balance between the environment and the socio-economic welfare of a region. In contrast to the conventional approaches employed so far, this is methodology brings forward an entirely new philosophy that sets higher, reliable and more comprehensive standards to environmental protection and safeguard of aquifer systems.

\section{Acknowledgments}

Results presented in this paper originate from a Thesis elaborated in the framework of the inter-departmental postgraduate course "Ecological Water Quality and Management at a River Basin Level" of the Aristotle University of Thessaloniki. The study was hosted and supported scientifically and technically at the National Agricultural Research Foundation-Land Reclamation Institute at SindosThessaloniki. The authors wish to acknowledge Emeritus Professor J. Koumantakis, School of Mining Engineering and Metallurgy, Geological Sciences, NTUA, Athens, for kindly granting access to data collected in the course of an extensive groundwater resources management research project.

\section{References}

Daskalaki P., Voudouris K., 2007. Groundwater quality of porous aquifers in Greece: a synoptic view, Environmental Geology, 54, 505-513.

Edmunds WM., Shand P., Hart P., Ward RS., 2003. The natural (baseline) quality of groundwater: a UK pilot study, Sci. Total Environ., 310, 25-35.

EC Directive 2000/60/EC of the European Parliament and of the Council of 23 October 2000 establishing a framework for Community action in the field of water policy. Official J. Eur. Communities L 327:1-72.

EC Directive 2006/118/EC of the European Parliament and of the Council of 12 December 2006 on the 
protection of groundwater against pollution and deterioration. Official J. Eur. Union, L 372:19-31.

EC Directive 98/83/EC, On the quality of water intended for human consumption, Official Journal of the European Communities, L 330, 32-54.

Hinsby K., Condesso de Melo MT., 2006. Application and evaluation of a proposed methodology for derivation of groundwater threshold values: a case study summary report, www.wfdbridge.net.

Griffionen J., Passier H., Klein J., 2008. Comparison of selection methods to deduce natural background levels for groundwater units, Environ. Sci. Technol., 42, 4863-9.

Koumantakis, J., Panagopoulos, A., Voudouris, K., Stavropoulos, X., 1999. Hydrogeological study of groundwater artificial recharge of the northern coastal and sub-hilly zone of Corinthia Prefecture. Final report (in Greek).

Lambrakis, N., Voudouris, K., Tiniakos, L., Kallergis, G., 1997. Impacts of simultaneous action of drought and overpumping on Quaternary aquifers of Glafkos basin (Patras region, western Greece). Environmental Geology, 29 (3/4), 209-216.

Müller D., Blum A., Hart A., Hookey J., Kunkel R., Scheidleder A., Tomlin C., Wendland F., 2006. Bridge Project, Deliverable 18: Final proposal for a methodology to set out groundwater threshold values in Europe.

Panagopoulos A., 1995. A methodology for groundwater resources management of a typical alluvial aquifer system in Greece, PhD Dissertation, The University of Birmingham, UK.

Panagopoulos, A., Voudouris, K., Hionidi, M., Koumantakis, J., 2002. Irrational water resources management impacts on the coastal aquifer system of Corinthia. Proceedings of the $6^{\text {th }}$ International conference Protection and Restoration of the Environment, Vol. 1, 419-426, Skiathos.

Panagopoulos A., Voudouris K., Koumantakis J., Hionidi M., 2001. Groundwater evolution of the northern Corinthian region coastal aquifer system, as indicated by Hydrochemistry, Proceedings of the $9^{\text {th }}$ International conference of the Geological Society of Greece, Vol. XXXIV, No. 5, 1991-1997, Athens.

Panoras A, Ilias A., 1999. Irrigation with treated domestic effluent, $175 \mathrm{p}$ (in Greek).

Pauwels H., Muller D., Griffionen J., Hinsby K., Melo T., Brower R., 2007. Bridge Project, Publishable final activity report.

Voudouris K., 1995. Hydrogeological conditions in northwestern part of Achaia. PhD thesis, Department of Geology, University of Patras (in Greek).

Voudouris, K., Lambrakis, N., Papatheodorou, G., Daskalaki, P., 1997. An application of factor analysis for the study of the hydrogeological conditions in Plio-Pleistocene aquifers of NW Achaia (NW Peloponnesus, Greece). Mathematical Geology, Vol. 29, No 1, 1997, 43-59.

Voudouris K., Panagopoulos A., Koumantakis J., 2000. Multivariate statistical analysis in the assessment of hydrochemistry of the northern Corinthia Prefecture alluvial aquifer system (Peloponnese, Greece). Natural Resources Research, Vol. 9, No 2, 135-143.

Voudouris K., Panagopoulos A., Koumantakis I., 2004. Nitrate pollution in the coastal aquifer system of the Corinthia Prefecture (Greece), Global Nest: the Int. Journal, Vol. 6, No 1, 31-38.

Voudouris, K. 2006. Groundwater Balance and Safe Yield of the coastal aquifer system in North Eastern Corinthia, Greece. Applied Geography, Volume 26, 291-311.

World Health Organization (WHO), 2006. Guidelines for drinking-water quality. 